\title{
TRACKING DOWNS CHRISTIAN DIOR IN AMERICAN POST-WORLD WAR II FASHION UNTIL EARLY 1950S
}

\author{
Nurina Aulia Haris \\ aulianurina.aulia@gmail.com
}

\begin{abstract}
This article studied the accomplishment of Christian Dior during his business venture in American market by using his autobiography as the main source of the research and qualitative research used as the method of study. Graves's thoughts on Consumer Behavior are used as the approach of study under the umbrella of Transnational American Studies.

The success of Dior in the American market is not solely because of his dresses but there are other factors that support the success of it. The post-World War II situation was a time when people need something new to remind them of their past glorious day and it was provided by Dior through his creations. In addition, the promotions and assessments from fashion experts through fashion and lifestyle magazines also affect people's assessment of Dior's dresses and affected them to own his collections. Based on the theory described by Graves, people tendency to imitate others is capable to influence one's expenses and this can be seen from the phenomena occurring in American society toward Dior's works at that time.

Concisely, the result of this research shows that the success of Dior in American market happened because of two things. First is the nature of human being that loves beauty, neatness, and things which make them happy. Second is the timing of his debut which matched to what people searched: the pride they lost during the war caused by the limitation applied by the government and the condition itself. Therefore when Dior came with his collections they saw it as if it was their way to get back their pride as by wearing Dior's collection it can show their social status.
\end{abstract}

Keywords: Christian Dior, Fashion, Societies, World War II

\section{Introduction}

Lotman in his book The Structure of Artistic Text stated that a society cannot life without an art because art is the result of culture (Lotman, 1977). In addition, Edward B. Tylor, an anthropologist, defined culture in his book Primitive Culture as "that complex whole which includes knowledge, beliefs, arts, morals, law, customs, and any other capabilities and habits acquired by [a human] as a member of society” (1873: 1). Base on the two experts, all of the things done and produced by human being is culture which means that culture and human being are two things that cannot be separated.

In the United States, culture becomes central because it is composed by many cultures coming from around the world. Besides the white Anglo-Saxon culture brought by the puritan to US since $19^{\text {th }}$ century from European countries, the 
common cultures in the United States are the Native Americans, African culture, Latin America and also Asian (“American Culture”, 2015). As a result, their familiarity in receiving new culture and their belief in freedom of expression make it easier for new culture to enter the country.

During the World War II, even though America did not experience it in their mainland they still can feel the impact of it as thousands of men were sent to the war which resulted most of American women had to take over male job in order to keep its country economic stability. One of the impacts from female taking over male job was that they need to change their outfit which fit their job. In addition, American government also regulating new rule regarding fabrics utilization in outfit making and also outfit style for women to be worn as their daily basis. Based on government regulation, the length the skirt was restricted not too long and not too short so that it can maximized the consumption of fabrics, daily gown was also made multifunction that can be worn as both day and night dress. Designers were ordered to make a new trend which suits the regulation during and postwar with the intention to preserve the rule (Olds, 2001: 47-49).
The situation in America and its characteristics have significant role in giving success to Dior and French fashion industry. For Dior, its openness and situation have made his job easier in running his business there while for French fashion industry, Dior successful venture helped the revival of French fashion industry as French designers started to gain more confidence in restarting their fashion business.

During World War II French fashion is considered 'dead' by not only fashion critics or fashion magazines editor but also many French designers themselves as they started to close their 'house'. However, a light of revival is seen from the blow of Christian Dior in February 1947 when he first shown his collection through a fashion show which he named it the "New Look" and received good reviews from many fashion editors and critics. Pochna citing Carmel Snow, The Harper's Bazaar editor in chief who states after seeing the fashion shows of Christian Dior that "It's quite a revolution, dear Christian! Your dresses have such a new look!” (Pochna, 1994: 9). His debut success in France spread throughout European countries and to the United States. Through his 'New Look', he had a chance to expand his business to America brought by Neiman Marcus Corp. 
and was awarded an "Award for Distinguish Service in the Field of Fashion” from Neiman Marcus Corp. or commonly known as the "Oscar" of fashion world. However, all of his success was not only followed by the sweet results but also the bitter ones. With all of the praise he received, there are people who showed protest toward what Dior has done. Alexandra Palmer-the Senior Curator, Nora E. Vaughan Fashion Costume Curatorship—states:

When Christian Dior's extravagantly feminine New Look burst upon the fashion-starved post-World War II scene, not everyone accepted itFrench saleswomen literally tore the dresses apart, spawning numerous anti-New Look protests. A glimpse into the rise of-and shock waves caused by-a fashion icon (Palmer, 2010: 25).

The phenomenon attached in Dior, the events happened after his debut, was the topic of this paper. Mainly to the reaction of American people gave toward him and his creations. In more detail, on how he first enter the market and his way to maintain his existence there and also his influence toward American societies especially those who wore his dresses. This phenomenon is further discussed using Graves’ Consumer Behavior.

\section{Methodology}

This article is conducted under the discipline of American Studies. Sykes on American Quarterly published by The Johns Hopkins University Press defined American Studies as "the study of American culture". Furthermore he explained that the main idea of it is the word 'culture' which brings both theory and method. In addition to that, he stated," The materials studied may be literary, but the approach will be that of the student of culture, not the critic."- "It is concerned with a culture which can be defined according to certain spatio-temporal dimensions” (1963: 254).

Additionally, quoting from Stanley Bailis in his article The Social Sciences in American Studies: An Integrative Conception, he mentioned the difference between American Studies and other disciplines in which they rarely allowed its scholars to conduct a multidisciplinary research. The following statement from Bailis supports the flexibility of American Studies as an interdisciplinary study which makes its scholars possible to conduct a research using multiple theories and methodologies from other disciplines (Bailis, 1974: 203).

American Studies has been highly responsive to the fluxion of its 
historical surroundings. The field has thus emerged not as a discipline, but as an arena for disciplinary encounter and staging ground for fresh topical pursuits (ibid.).

The interdisciplinary of American Studies enable the discipline to take theories and methods from other disciplines and make them suppler than others. Furthermore, Rowe in A Concise Companion to American Studies described the characteristic of American Studies as:

No longer focused exclusively on consensus history and assimilationist ideals, American Studies takes into account the many different and constantly changing communities that constitute the United State-The new American Studies is also attentive to the ways the US has participated in traditional imperialism, both in Manifest Destiny and slavery (Rowe, 2010: 7).

Additionally, he also mentioned the broad object study of American Studies which can include "all of the different nations and communities of the western hemisphere" and "the field should be understood as profoundly comparative and transnational, even when it concentrates exclusively on the internal diversity of the US (2010: 8).”

In this occasion the writer applied Transnational American Studies as the umbrella theory and conducted the research using Philip Graves's thought about consumer behavior. Emory Elliott describes transnationalism as "genuine inclusiveness and broad international collaboration (2007: 6)." Then the importance of transnational in American Studies based on Fishkin is that it enables American Studies to participate in a global phenomenon as it studies the cross border of the nation, more specifically Fishkin said that:

We are likely to focus not only on the proverbial immigrant who leaves somewhere called "home" to make a new home in the United States, but also on the endless process of comings and goings that create familial, cultural, linguistic, and economic ties across national borders - and more on the nation as a participant in a global flow of people, ideas, texts, and products (2005: 24).

Moreover, Fishkin also brought up the idea regarding the participation of "local spaces in global phenomena" in which they participate on the "[internal] and [external] migrations, the diffusion of cultural forms, the spread of capital and commoditiesand all the attendant consequences (ibid.).”

Transnationalism has given the picture of American Studies as a discipline which enables its scholars to see the dynamic flows and the relations of human life-economic, culture, linguistic, etcacross the borders of American nations. Rowe explained that "border studies" in American Studies tried to see the cultural 
hybridity as one of aspects which constituting the United States. Therefore transnational American Studies makes its scholars be able to witness the contact between America and other nations and how they influenced each other especially American influence toward other nations and "to work genuinely as a comparatist discipline" but "rather than treating such cultural differences as discrete entities, however, this new comparative approach stresses the ways different cultures are transformed by their contact and interaction with each other (Rowe, 2000: 24-25).”

\section{Transnational American Studies} provided the bridge to the writer to explore how Christian Dior as a French couturier spread his career in America and how both of them influence each other. The autobiography Dior wrote and biography about Dior from other writers provide the information on how they influence each other in good and bad ways.

According to Graves in his book consumerology people are likely to follow what others done and even stressed the point that this behavior is actually one of the indications which differentiate people to other creatures (2015: 53). This thought is important as it can strengthen the reason on Dior massive acceptance in America and hypothetically shows that people behavior can influence their expenses. There are two points from Graves's thought that is used in analyzing this research they are priming or the first impression of a product (2015: 56) which he said that it really influential to the success of products (2015: 58) and environment of the market place (2015: 61). Moreover, he also stated that the cycle of fashion trends often happen because people are influenced by their surroundings (2015: 55). Additionally, they are unable to differentiate what they need just because others owned that (2015: 55).

Regarding the method of the study, it takes document analysis as the method of the study by using two types of data: the primary and secondary data. The primary data is Dior autobiography while the secondary data are the journals, documents, and articles regarding the study. The study was conducted by observing the use of word choices, metaphors, phrases, and others from the data that are used to describe the relationship between Christian Dior and the United States.

\section{Discussions}

\section{Christian Dior and American Market}

Fashion industry in America was growing better and becoming one of the promising industries there. The development of American Hollywood 
movie also becoming one of the aspects which boosting the growth of American fashion. Decades later, 1930s to 1940, when everything was more modern also American fashion becomes more sophisticated, New York became one of international fashion center with the mushroomed of American high fashion brands under notable designers such as Elizabeth Hawes who became one of America's prominent designer that helped creating the birth of American style in 1930s.

American fashion began to gain recognition and assert its place during the 1920s and 1930s. Hollywood helped by providing America and the world with the latest ideals of feminine beauty and glamorous dressing. As women saw their favorite stars in exciting new fashions, the demand for these garments transformed the costumers to designers in their own right (Mschoeny, 2001).

The growth of fashion industry placed the designers as the decision maker of a fashion trends, people who created trends among the societies and so did Dior. In 1947, Dior started his career as a fashion designer in Paris and got a great welcome from the societies not only in France and Europe but also America. Dior success in his homeland made Neiman Marcus Corporation proposed to open his store in their department store in Dallas, Texas. Moreover revealed by Dior that Neiman Marcus department store "offers the most expensive things in the world to the wealthiest buyers (Dior, 1957: 65)" which also signified that Dior collections is an expensive one which specialized for certain group of people that make it special and can be used as a tool to differentiate someone’s social class.

The appearance of Dior in American market after World War II got various reactions from almost all group of people. For some people, the appearance of Dior was a medicine for women there to revive their confidence and fulfill their need of beauty because of the limitation they got during the war. Specifically, the emergence of Dior and his existence in America has helped them to get back their pride as a woman especially women from upper societies. In his autobiography, Dior said that his dresses was pointed for upper society women and can only be obtained by those who owned a lot of money. Therefore, in the writer opinion, by buying Dior dresses, it can help them to identify themselves and differentiate them from most people. The reactions Dior got was not only coming from the upper society but also the middle and lower society including American government that persuade their 
people not to buy his collections because it contradicted with their rules (Olds, 2001: 51). It happened because Dior intentionally creates his dresses by consuming a lot of fabrics. Besides fabrics utilization, another aspect from his collection which attracts people attention was the style he created inspired from hour-glasses. Carmel Snow, the editor of Harper Bazaar America said that Dior first collection was a revolution in fashion industry (Pochna, 1994: 9). Dior bravely create dresses which shows the form of women body that similar with hour-glass by adding corset to show the beauty of their body form which was different from the previous trend which gave more freedom for women since it did not utilize corset.

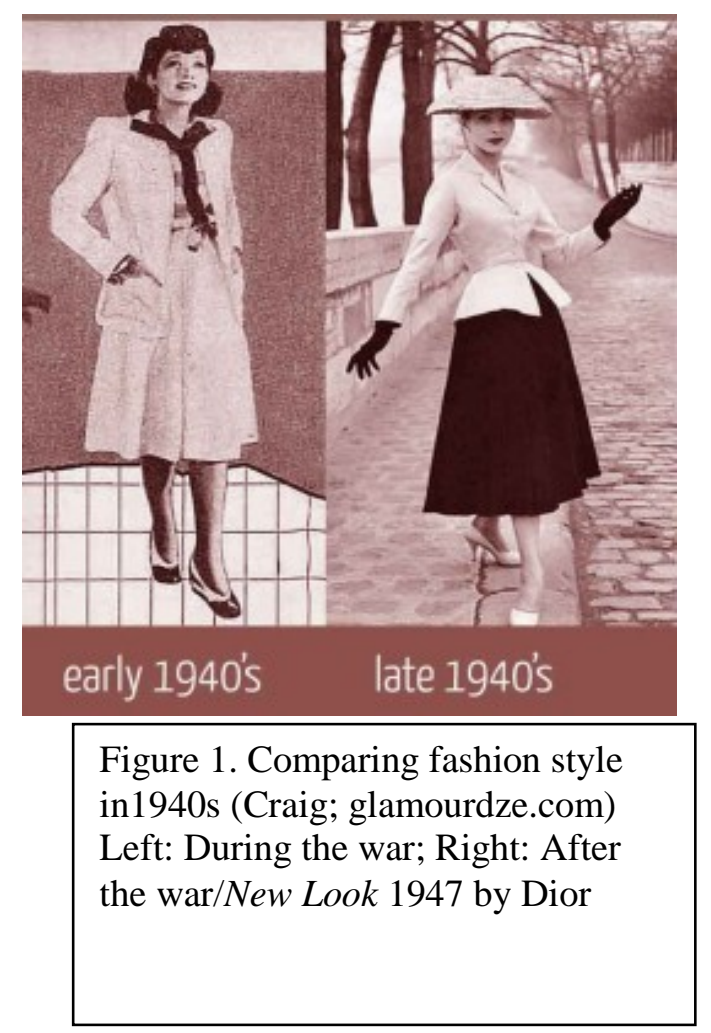

In another occasion, protests were done by people who rejected the existence of Dior either in New York or Paris (Olds, 2001: 51). Further, Olds explained:

Many women criticized the New Look for being too extravagant, wasteful, expensive, and downright unpatriotic. In addition, these clothes were simply too expensive, not to mention impractical, for the average woman. Others complained that the heavy corset and padding necessary to achieve the New Look undermined the newly-found freedom of women (ibid. 51).

In addition, Dior also received many complaint letters from husbands whose wife always wore Dior. In his autobiography he said,” A garage owner from Los Angles wrote and told me that he had sworn to "tear me apart" on his next visit to Paris. According to him, it was my fault that his wife looked like a stuffed doll of the time of the Civil War (Dior, 1957: 185).”

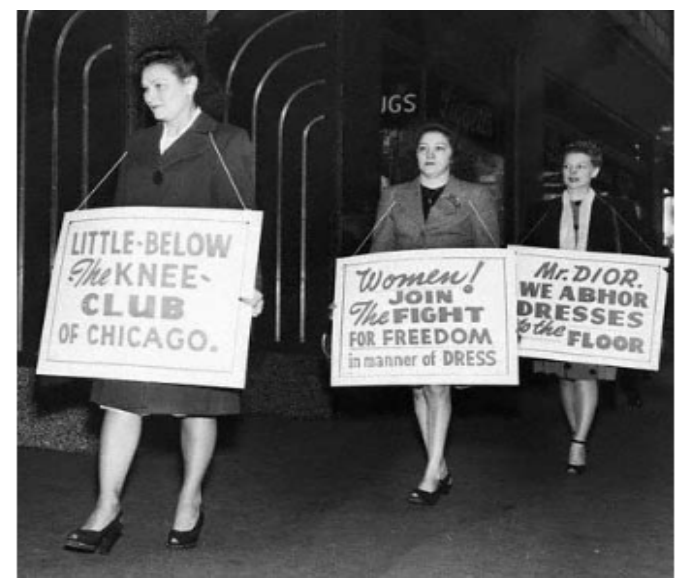

Figure 2.

American feminists, who demonstrated against the New Look. (Palmer, 2010: 28) 
In Louisville, 1,265 women believed that the New Look was not only impractical but also anti-feminist, and signed an antiDior petition as members of The Little Below the Knee Club-In Georgia, a group of outraged men formed the League of Broke Husbands, hoping to get ' 30,000 American husbands to hold that hemline' (Palmer, 2010: 27).

In the writer opinion, the negative and positive response he got were something common because everyone had their own idea in seeing something and it also the same the way they reacts to it. However, all of those responses were used as promotional tools because all of that made people familiar with Dior. In his opinion, Dior said that gossips and negative comments from people "worth more than the most expensive publicity campaign in the world (Dior, 1957: 34) and was a "firstclass free advertising (ibid.).” In spite of all the negative response he got, Dior still maintains his place as a prominent and influential designer.

\section{Priming (First Impression) and Marketing Strategy}

Marketing strategy is important to determine the success of a business because with a good marketing strategy a business can be famous and become a trend among societies. In the case of Dior, by wisely taking and employing every chance he got, he can change his fate in its best condition.

As a fashion designer who expand his empire to America, he need to know the condition and the demand of his American costumers in order to meet their satisfaction and be able to keep their trust to him. Therefore by knowing the difference of French and American clientele he adapted it by making slight differences in his dresses which was marketed in France and America. Additionally, he also understood the culture of both French and American women regarding their habit in spending their money. French women tend to buy 'the quality over quantity' while American women was 'the quantity over quality'. For American women, as they know that what they bought will soon consider outdated they tend to do not mind the quality (Dior, 1957: 76-77). This kind of situation was often benefitted by Dior and his team to market their products. The following topic will talk about another strategy and his belief in producing his collections. The topic is discussed by using Graves's thought about priming or first impression toward a certain product and also the environment where Dior products were marketed. Graves explained that priming or first impression can shape or influence 
people's thought and opinion then they will look for proofs that match with their impression (Graves, 2015: 55).

Priming or the first impression is an important aspect in marketing products because the first impression can last longer in consumers mind and it can influence their decision whether they will buy the product or not (Graves, 2015: 55). In his book, Graves gave an example how priming influence the way people think. The experiment he did is giving question on the following problem. People were asked to guess the answer of $1 \times 2 \times 3 \times 4 \times 5 \times 6 \times 7 \times 8 ?$ and

$8 \times 7 \times 6 \times 5 \times 4 \times 3 \times 2 \times 1$ ? . The average answer of the first problem was 512 while the second one was 2.250 however it actually has the same answer. The reason why people gave higher answer on the second problem was because the first digit of the problem is higher than the first one. They gave different meaning to the problem from the first digit they heard and estimated the answer based on their first assumption (ibid. p.56). If it is applied in marketing strategy, priming is assumed as the first step in building image on the prospective consumers mind therefore putting a positive image on a product can highly determine the success of it.
In conducting his business, Dior applied some strategy such as implementing the concept of limited edition in which he made limited pieces of his collections to keep the exclusivity of his products. Exclusivity is important since it can make the "commercial value" of the product become higher. In applying the concept of limited edition, Dior not only used it to his designs but also the material/fabrics he used to make the collection.

The next strategy was applying the concept of 'Tradition' as the key point in dress-making. Since the beginning of its establishment, Dior was made for fashionable women and arranged to meet Dior desire to preserve French fashion tradition which refers to luxury (Dior, 1957: 21). He also said that,” I envisaged my house as a 'craftsman's workshop,' rather than a 'clothes factory" (Dior, 1957: 21). It shows how persistent he was to keep the tradition alive in his house. In term of dress making, Dior is applying 'Old Style Tradition'. The 'Old Style' here was not implying to the older style of fashion but here he emphasized on the tradition. The tradition he keep in making the dress is the technique during the process of dressmaking which exist since before the war (Dior, 1957: 45). Since the old 
technique of dress making Dior wants was coming before the war, there were not many skillful dress maker left as the result of the war therefore it is difficult for Dior to look for more member to his 'house'.

I wanted my dresses to be constructed like buildings, molded to the curves of the female form, stylizing its shape. I emphasized the width of the hips, and gave the bust its true prominence; and in order to give my models more "presence," I revived the old tradition of cambric or taffeta linings.-My return to long forgotten techniques raised a host of difficulties for, of course, none of my staff had any experience with them (Dior, 1957: 40-41).

Then there were also 'Clientele Treatment' which he applied in order to make his customers feel more comfortable. In capitalist society, client is the king and need to be served at their best. This concept was applied by Dior to his clienteles. Every client will be served well to make them comfortable and feel as they were the most special one. In his house, each of his clientele will be given a staff especially to treat them from the process of order until the delivery of the dress to each clientele. The personal staffs will always presence every time the clientele come to the house for fitting or revising the dress. This strategy was applied to make the clientele comfortable and feel that they were cared.
The last is fashion show. Then there were a regular fashion show he held to keep his clientele informed of his latest collections. Dior debut in 1947 was anticipated by many people since they heard that "by the summer of 1946 word was out that Boussac was backing Christian Dior” (Palmer, 2010: 26). The news was spread widely and "the opening of the new house was announced in the US in the winter of 1946 in Women's Wear Daily, and in French Elle in January 1947" (Palmer, 2010: 26). This event was a history in fashion world industry since it was marking the revival of fashion industry after World War II. The hype of Dior first fashion show was shown by not only the abundance of attendees who came to the show but also the fact that the invitation letter of the first show also sold in the black market (Palmer, 2010: 26).

Fashion show is one of important aspects for a couture house to keep their existence in fashion industry. It is one of the house ways to introduce their latest collection to the public. Dior, like any other couture houses always held a fashion show every season to make sure that their clientele keep updated with the newest trend. All aspects in the fashion show can also determine the selling of his collections as stated by Graves that, “Tingkat 
pencahayaan, suara ambient, aroma, produk-produk pelengkap, warna, musik, desain interior-baik dibuat secara artificial maupun alami, semua dapat mempengaruhi cara orang merasakan dan apa yang mereka pilih untuk dilakukan (Graves, 2015: 86)—“The lighting level, sound of the ambience, scent, complementary products, colors, music, interior design-either the artificial or natural, all of it can influence the way people feel and what they want to choose to do." Therefore Dior really gave a lot of thought in designing his fashion show hall as he decorated room with flowers, colorful fabrics match with the theme, lights, and even spraying some perfume (Dior, 19587: 135-136).

\section{Conclusion}

There are 2 things found in this paper which related to the success of Dior in American market. First is coming from the nature of human being that naturally love beauty, neatness, and things which can make them happy, specifically happened because a group of people wanted to bring back their pride which was taken by the war. Then, there was timing that became the second important things in the writer opinion which support Dior success in America. Post-World War II situation, people need of luxury as their reminder of their past glorious days-which has been mentioned previously that it related to their pride - and the influence from the massive information from the influential people in fashion industry were some aspects which support his success there. People tendency to easily influence by others also helped Dior to vastly spread among American society especially women who were coming from the upper society as his main consumers. As a fashion designer and a businessman, Dior was quick in reading the demand of the society and efficiently adapted to it. Many people fall to his marketing strategy so that they did not think much to buy his collections. By employing human nature which loves to be taken care and treated as an important people, Dior was able to maintain his market and attract more consumers. Additionally, because there were many fashion houses which was difficult to restart or maintain their business, he did not have many competitors that can harm him in the industry which resulted to make him stay in the spotlight. In the end, his success was placed in his ability in reading the situation where after the war there were many people especially women who long for their previous luxurious life. 


\section{References}

Bailis, Stanley. 1974. "The Social Sciences in American Studies: An Integrative Conception." American Quarterly 26: 202-224. Document.

Craig, Tia. World War Two Fashion (glamourdazed.com/world-wartwo-fashion/post-wwii-influencein-the-1940s). 11 July 2011. Pictures. 25 April 2017.

Dior, Christian. 1957. Christian Dior and I - New York: E. P. Dutton \& Company Inc.

Elliott, Emory. 2007. "Diversity in the United States and Abroad: What Does It Mean When American Studies Is Transnational?" American Quarterly, Vol. 59, No. 1: 1-22. Document.

Fishkin, Shelley Fisher. 2005. "Crossroads of Cultures: The Transnational Turn in American Studies-Presidential Address to the American Studies Association, November 2004." American Quarterly, Vol. 57, No. 1: 17-57. Document.

Graves, Philip. 2015. Consumer.ology: Mitos Riset Pasar, Kebenaran tentang Konsumen, dan Psikologi Belanja. (Translated Version). Jakarta: PT. Elex Media Komputindo. Document.

Lotman, Jurij. 1977. The Structure of The Artistic Text. USA: Brown University Press. Document.

Mschoeny. Fashion American Style: 19001999 America's 20th Century Rise to Dominate World Fashion. 26 October 2001. Document. 9 May 2017.
Olds, Lauren. 2001. "World War II and Fashion: The Birth of the New Look." Constructing the Past: Vol. 2 : Iss. 1 , Article 6: 47-64. Document.

Palmer, Alexandra. Dior's Scandalous New Look. $\quad$ Spring 2010. https://www.rom.on.ca/sites/default/ files/magazine/spring10_feature.pdf . 25 September 2016.

Pochna, marie-France. 1994. Christian Dior: The Man who Made the World Look New. New York: Arcade Publishing, Inc., Document.

Rowe, John Carlos. 2010. A Concise Companion to American Studies. The United States: WileyBlackwell. Document.

Rowe, John Carlos. 2000. PostNationalism, Globalism, and the New American Studies. California: University of California Press, Ltd., Document.

Sykes, Richard E. "American Studies and the Concept of Culture: A Theory and Method." American Quarterly, Vol. 15, No. 2, Part 2: Supplement, The Johns Hopkins University Press (Summer, 1963): 253-270. Document.

Tylor, Edward B. 1873. Primitive Culture: Researches into the Development of Mythology, Philosophy, Religion, Language, Art, and Custom. London: John Murray.

Zimmermann, Kim Ann. American

Culture. 15 January 2015.

Document. 20 June 2015.

$<$ http://www.livescience.com/28945

-american-culture.html> 